\title{
Autofrictions
}

\section{The Fictopoet, the Critic and the Teacher}

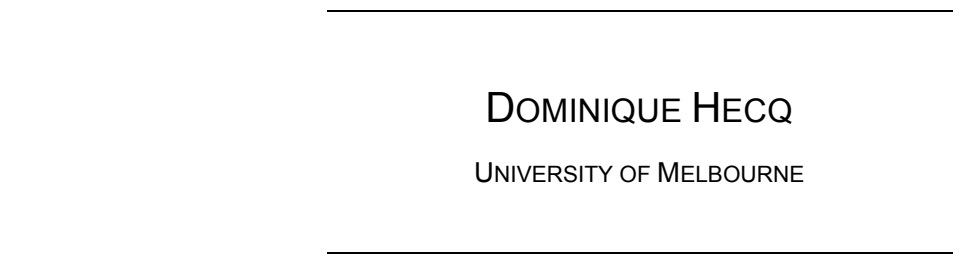

Writing forms a passageway between two shores.

Hélène Cixous ${ }^{1}$

The dissolution of boundaries between creative and essay writing overtly or implicitly advocated some thirty years ago in the USA by the 'language poets' and in France by feminist writers has been confirmed by the more recent adoption of the term 'fictocriticism' in Australia. ${ }^{2}$ One of the lessons to be learned from such radical works as those gathered in Heather Kerr and Amanda Nettlebeck's edited collection, The Space Between (1998), is that neither poetic nor critical language can any longer claim to be impervious to the debates that have dominated academic and philosophical thought for the last thirty years. ${ }^{3}$ The theoretical and political concerns that inform the speculative and often poetic prose of the women whose work figure in The Space Between, for instance, proves congenial to academics engaged in deconstruction, cultural studies and interdisciplinary approaches to art and literature as well as to teachers of creative writing at tertiary level. The paucity of critical material on this kind of work, however, has the disquieting effect of reminding us that we still lack the critical vocabulary to re-examine the paradoxes built 
into some of the most exciting work done in Australia over the past few decades, let alone to teach them.

This paper investigates the literal, metaphorical and ideological implications of 'hybrid' texts/genres for criticism in general, and for the workshopping of creative work in particular. The question underlying this investigation concerns the place of poetic discourse in fictocriticism. This is consonant with my understanding of genre as 'index and mark' representing 'the site of the nonsubstitutable positioning of the $I$ and the you and of their modalities of expression' and of poetic discourse as 'an unsettling process ... of identity of meaning and speaking subject'. ${ }^{4}$

I am, of course, aware of my effrontery. As we know, any genre is still in the process of becoming, and it is its proper essence that it is always only becoming, and that it is never capable of completing itself. No theory can exhaust it, and only a clairvoyant sort of criticism could dare to characterize its ideal. ${ }^{5}$

Moreover, while I might at first give the impression of indulging 'the impulse to hierarchise', or at least to categorise, I am keen to 'allow differences to co-exist and to refuse the will to colonise'. ${ }^{6}$ Because this is in itself an aporia, I am, however, also of the opinion that 'fictocriticism ... frankly requires a geometry of borders, boundaries, regimens of disciplinary protocols in order to produce a doubtful "space between"'. As a teacher, I am, whether I want it or not, regulated by the discourse of the university with its institutional, pedagogical and ethical specificities. ${ }^{7}$

Poetry is like a swoon, with this difference:

It brings you to your senses

\section{Bernstein}

But first, because so much of the rhetoric around fictocriticism focuses on this 'space between', the gap between discourses where knowledge can be intuited, articulated or performed, I'd like to reflect on the possibilities of such a space. Fictocriticism may well be regarded as 'a local response to a general critique of the forms knowledge-production takes, as well as an accompanying scene of academic community formation that tend[s] toward the transdisciplinary as much as the transgeneric', it nonetheless produces knowledge, or at least a trace that is also a hint reminiscent of the possibility for knowledge-production inherent in poetry. ${ }^{8}$

So, let me take you to this other shore where silence is also knowledge. Where the letter is litter. Where stars are clouds are sand.

The French psychoanalyst Jacques Lacan conceived of literature as a series of holes and erasures. In an essay entitled 'lituraterre' he meditates on the letter as constitutive of the subject (and of sexuality) as that which is written. ${ }^{9}$ In Latin, literatura signifies writing, grammar, learning or literature. However, literatura derives from the verb lino, for 'I smear', 'I cover', 'I erase'. As Freud and later Kristeva have shown, the roots of languages from Ancient Egyptian to 
present-day German, French and English comprise antithetical meanings. ${ }^{10}$ Literature belongs to this category of words,

at least in so far as its roots provide us with a divided image: we see a hand covering a tablet with wax or another inscribable substance, while the same hand, or a different one, is erasing the tablet so that it might register other signs. ${ }^{11}$

Literature, Lacan suggests, is related to the Latin litus, meaning either the act of smearing or covering, or littoral, a shore. Thus the word literature generates a double pun: it suggests both letters and their erasure as well as the limit or border of a territory such as the sea or the rim of the hole in knowledge':

... the original stroke and what erases it. As I said, it is from their conjunction that the subject emerges, but when two moments are marked off. The erasure must therefore be noticeable.

Erasure of no trace that would have been there before, this is what makes a land of the littoral. Pure litura that is the literal. To produce it means to reproduce this half without its other half from which the subject subsides ... 12

Thus the letter produces a 'hole' where knowledge and jouissance coalesce and writing is that which touches upon knowledge and jouissance through contact with the border in the space 'between centre and absence, between knowledge and jouissance'.13 Here is perhaps a clue towards an understanding of knowledge-production in poetic discourse. As well as a clue towards an understanding of knowledge-production in hybrid genres where knowledge arises from the clash between the literal and the metaphorical in the gap between the public and the private, the discourse of criticism and auto/fiction.

What is fiction? What is creative non-fiction? What is criticism? Where does prose stop and poetry begin? What is an author? A fake author? A criminal word-snatcher? And what aesthetic, ideological and marketing purposes are served when we begin to call things by certain names? Does the very gesture of calling the blending of different discourses suffice to create a piece of fictocriticism or have fictocritics effectively developed specific compositional strategies meant to erase accepted distinctions between literary genres and expand the range of formal possibilities of contemporary writing? If that is the case, are we speaking of fictocriticism as a seamless continuum liable to be transgressed by its own inherently subversive potential? Or is fictocriticism in the process of becoming another genre with its own methods, conventions and fashionable trends? And finally, is the term 'fictocriticism' redundant, since for some, 'all writing is writing, and in the act of writing-as Daniel Chandler notes-“all writers join an existing and ongoing textual conversation ... across genres and rhetorical modes"'? ${ }^{14}$

Writing: 'a passageway between two shores'. ${ }^{15}$ 
These questions are some of those Anna Gibbs addresses, directly or indirectly, in 'The Gift' and in its 'Afterword', both published in The Space Between, a twin-text that I choose for its pedagogical potential, that is, the possibility of deconstructing its own bricolage. 'The Gift' is divided into ten subsections; the first fragment, ironically titled 'It's no use at all', proceeds to investigate the literal, metaphorical and ideological implications of the name, the personal pronoun, the gift. The very form of Gibbs's text-a 'cut-up piece' that stages 'a collaboration between Marcel Mauss, the anthropologist of the gift, and Colette, the writer of fiction whose signature actually conceals four figures essential to her literary production'-is a (self-) ironical comment on the transgressive power of experimental writing, a gesture the author later defines as 'a literal enactment-a practical demonstration-of contemporary understandings of the nature of textual production as inevitably a kind of rewriting. ${ }^{16}$ This 'hybrid' text foregrounds the clash between various forms and uses of discourses by blurring categories between anthropology and autobiography, objectivity and subjectivity, prose and poetry, philosophy and fiction. Central to this work is the distinction between gift and debt, which ultimately draws attention to the undecidability and indecipherability of a text that emblematises sexual politics. Although Gibbs might have some reservations about the more decorous quality of Derrida's margin collage Glas, her work partakes of a similar impulse to challenge the distinctions between so-called 'literary' and 'philosophical' texts while simultaneously forcing us to revise and politicise our understanding of such distinctions. ${ }^{17}$ 'The Gift' ends with a muted call for some more communal and emotionally committed writing/reading, some form of communication:

For now, written in the margins of other authors, are the signs of my own existence, the letters I freely wrote without hope of reply to an unknown woman, perhaps now dead? Not yet living? Still, memory-if this is not too brutal a name for something one cannot analyse-bequeaths me a curling wave of feeling, a sense of a breathing presence, a lit face close to mine ... I wrote to a woman capable of reading anonymous books hidden in grey traceries of lace among the rocks of classical writings. All the things I could say aloud to no one I entrusted to a terribly dilapidated copy of European folklore, exposing to her there, between the short, rhymed fables, the thoughts and feelings I feared studying myself in the too bright light of the blank page. Almost every secret flight whispered to her of the truth that shaped itself within me. It was at the same time property and possession, a pledge and a gift.

At any rate, something better than mere silence. ${ }^{18}$

Witnessing the direction that cross-cultural fictocriticism has taken, it would seem that Gibbs's call has been answered, as it purports to rely 'on a politicised sentimental imagination that aims to enhance our capacity to be affected by the effects of history'. ${ }^{19}$ 
Fictocriticism, perhaps more than any other genre, has been involved from the start in a systematic critique of its own formal and ideological foundations as well as of the relationship between reader and work. In the hands of some practitioners, it has also helped to question the binary thinking that draws a clear-cut line between creative and critical material while undermining what the American poet Bob Perelman once described as the 'Manichean model of / a prosy command-centre of criticism and / unique bivouacs on the poetic margins'. ${ }^{20}$ Indeed, part of the project of fictocriticism seems to extend to the question of whether generic, functional or modal, as opposed to merely structural, categories like 'fiction' or 'criticism' can reclaim other genres, functions and modes, which have become associated more or less with poetry and philosophy. It could be argued that in Australia fictocriticism has thus moved beyond the scope of feminism and poststructuralism, for the writers I discuss here have (un)wittingly used these theoretical frameworks to wider poetic ends. ${ }^{21}$ Fictocriticism, indeed, also argues for the coexistence of simultaneous and heterogeneous spaces in the mode of presentation and representation.

Because of its continual oscillation between the literal and metaphorical margins and marginalities implicated in fictocriticism, this genre, or mode, has been used to seize upon not only the contradictions, but also the possible negotiations between the 'public' utilitarian language of prose and what is often perceived as the oppositional and marginal status of poetic language. A meditation on suicide by Dean Kiley illustrates this quite well. ${ }^{22}$ 'Alone, Again: Naturally (and Queerly)' is particularly useful in workshops because, like some postmodern buildings, it leaves the scaffolding about, as it were, for the reader to deconstruct. Kiley's piece opens with a commentary on Beverley Farmer's Alone and introduces queer criticism through a montage of quotations and his own poetry. ${ }^{23}$ Yet it is Kiley's interspersing of quotes from Jeanette Winterson's 'Art and Lies' with his poems 'being ghosted' and 'apparitional' that opens up the space for new knowledge. Intuitive knowledge. ${ }^{24}$ The knowledge one hears in the silences of poetry-'the cloud of language' Lacan alludes to in 'Lituraterre'.

But perhaps Gail Jones's texts are among the most rewarding in this respect. One of the most remarkable features of Jones's work is its willingness to integrate many different discourses from areas such as philosophy, science, ethnography, psychoanalysis, feminism, narratology, narrative and the lyric. Yet Jones's work is memorable not for its polygeneric quality but precisely for not confining itself to mixing or juxtaposing antipodal modes and registers. Up to and including her newly published novel Sixty Lights, Jones's achievement lies in the poetic intensity inherent in her playful and critical appropriation of various discourses. ${ }^{26}$ Unlike Kiley, who resorts to and restores the asyntactic and disjunctive strategies encountered in many experimental works taking their cue from a poststructuralist or postmodern aesthetics, Jones proceeds to undermine from within the logical, syllogistic authority of expository prose by confronting it with the changing psychic terrain displayed by a consciousness that is using all its 
rhetorical vigour and poetic intensity to keep up with the accelerating frame of wor(l)ds edging away. Perhaps she does achieve, finally, what she called 'starry text' in an elegiac essay on grief:

I am not quite prepared to relinquish communion with the stars, but I do wonder how one might achieve the starry text. How does one honour, in grief, all that up-rises? And how then does one write of it, other than by employing these oddly cathected masques and stylistic hesitations? I suppose there must be somewhere a metaphysics of asterix, some sparky exclamation at the very fact of existence, and perhaps one dedicated not to black sky, but to the lapis-blue and astrous weather of the gift. ${ }^{27}$

As is apparent in this fragment, Jones's writing conveys the particulars of subjective experience in a way that accounts for the geometries of language and subjectivity to combine them in an alternate, less linear, logic. The constant shifts from the general to the particular, the abstract to the sensuous, the metaphorical to the literal, need to be understood in the context of the author's proposition that 'writing, or its theorizing, must somewhere include the lost woman abolished to shadows'. ${ }^{28}$ What I find particularly appealing in Jones's work is that the transitions between discourses always remain fluid, achieved as these are by almost unnoticeable shifts in tone, register and grammatical structure. By doing so, her work suggests one possible way out of the epistemic gaps allegedly separating philosophical and poetic language: to incorporate them in an alternative form of knowledge that combines the heuristic with the speculative, thus invalidating Alain Badiou's point that 'the literary act, whose kernel is the poem ... is specified for philosophy as fiction, as comparison, image or rhythm, and as narrative'. ${ }^{29}$

Such concerns are not new, of course, even in the context of the history of Australian writing, nor are they restricted to the writers or works cited above. Over one century ago, Christopher Brennan read a paper before the Sydney University Philosophical Society where he publicly endorsed Novalis's plea for philosophy to 'become a commentary on poetry', arguing that 'philosophy is a necessary commentary on all perception' ${ }^{30}$ Some of Brennan's writings on philosophy, aesthetics and poetry, in fact, point in the direction of a work suspended between his ideal of the self-sufficient poetic artefact and the contextual discursiveness of the essay. 'What is Poetry?', for instance, both echoes and performs the struggle between poetic ambiguity and the objective value of the essay that is still typical of many contemporary works of poetry written in prose, so to speak. The idea that poetry, philosophy and prose involve commitments that are both similar and complementary is also evident in the work of AD Hope, Gwen Harwood and Kevin Hart. But I am digressing.

While the few writers discussed so far seek to push the borders of language by hybridising prose fiction, poetry, philosophy and other discourses in fictocritical essays, others have written pieces that take the form of fables, parables or short stories. Indeed, a consistent feature of fictocriticism concerns the possibility of reclaiming for criticism the storytelling functions of 
narrative prose fiction, a popular direction that now also promises 'a genre to come' in the guise of the 'thesis-film'. ${ }^{31}$ Conversely, it concerns the possibility of reclaiming for fiction the speculative functions of various modes of inquiry. What most new writers share, though, it seems to me, aside from their rhetorical sophistication, self-reflexivity in the guise of foregrounding of form and/or discourse, intertextual forays, genre-bending/crossing, political awareness and ubiquitous versatility, is their readiness to make the literal metaphorical and the metaphorical literal, thus bending genres further: prose is increasingly poetic and poetry increasingly prosaic (in the sense of having the character, style or diction of prose, not lacking poetic beauty) as though we are indeed intent on hitting the 'kernel' of the literary act. Perhaps this is best illustrated in the rather aptly titled 'Outside In' issue of the Cultural Studies Review where three of Michael Farrell's fictocritical poems appear between Tara Lee's poetic essay on 'The Skin as a Map of Personal Memory' and Stephanie Bishop's fictionalised essay on poetics as an allegory of love. ${ }^{32}$ And note that all three sets of writing, linguistically self-aware and performative that they are, also foreground ontological and ethical concerns.

Michael Farrell's prose poems seem to veer in the direction of what Derrida regards as the basic constitutive feature of Maurice Blanchot's The Madness of the Day, a text staked on 'the possibility and the impossibility of relating a story'. Despite this, it does seem that we are heading towards a poetic détournement of some type of prose whose sustenance is a 'thinking that makes ... storytelling possible'. Here the focus is on the intellectual leaps that allows stories to be told in ways that underscore the rhetorical groundings of both poetry and narrative, the shore where philosophy begins:

when it is no longer a question of interpreting the real procedures where truth lies, but of founding a unique place in which, under the contemporary conditions of these procedures, it may be stated how and why a truth is not a sense, being rather a hole in sense. ${ }^{33}$

This is ironic, of course, in view of the overall distrust of poetic rhetoric that largely characterises modern Australian poetry.

Does this mean that fictocritics are heading towards writing poetry that 'brings you to your senses' in an age of prose ? $^{34}$

It would seem that this might be the case. Most telling for me, perhaps, was Jennifer Rutherford's presentation at a recent conference on 'Anatomy and Poetics'. Rutherford, who has repute as a cultural and psychoanalytical critic, performed a poetic piece entitled 'Clay Cloth Corps', which both illustrates and critiques Lacan's understanding of the sexual relation. In that respect, Rutherford goes further than Jones in that she brings the body in between subjectivity and texts from a radically feminine position:

There was a moment when it all seemed possible. To make love and to make. I wanted to make a pot that would pour children and works. I 
wanted to write a story about love; that new story women keep trying to make; the joyous one about women making. But as the story unfolded it became more and more saturated with pain, the writing dense with it even as I tried to break through. What? That impossible membrane; a circle of clay, of cloth that encloses my empty space. Me. And then it all dovetailed into being made; being made into that thing a woman is-always being made into. I began to see that the joyous story about women making themselves and their works couldn't be told unless we began from what we were being made into every day. In this story I just end up as a pot. An old discarded empty pot. But a pot is the first signifier; it holds; it contains. From ex nihilo an empty space and in that space-everything.

And the 'I' speaking from that space in between two shores-an emblem of the solitude of the subject.

That solitude, as a break in knowledge, not only can be written but it is that which is written par excellence, for it is that which leaves a trace of a break in being. ${ }^{35}$

Thus, although Amanda Nettlebeck drew attention to fictocritics' inclination towards playing 'upon metaphor and metonymy' when she located fictocriticism 'at the intersection of literature and postmodernism', as 'a way of speaking, a mode of performance' in which 'the distance' of the theorist/critic collides with the "interiority" of the author', she might not have anticipated such a return of the repressed in the guise of poetry. ${ }^{36}$ Yet it would seem that what most recent works have in common, besides a highly self-reflexive stance, is a poetic or metapoetic mode informed by an awareness of the complexities of narrative as well as of the irremediable fissure between the writing and the written subject. With their emphasis on the madness of 'expecting truths-of ourselves, of the world', the writers cited here conceive of writing as an art of intellectual patterns that deliberately foregrounds what could be called the anti-readerly subjective premises of the lyrical mode. ${ }^{37}$

Does this make fictocriticism a marginal genre, and does it matter?

Poised between the centre and the margin, between the public discourses of criticism, cultural studies, ethnography, feminism, history, linguistics, philosophy, psychoanalysis and so on, and the private discourses of autobiography and poetry, fictocriticism problematises the linearity and coherence that we have been taught to expect from texts focused on information rather than knowledge and urges us to explore those axiomatic forces that shape literary traditions, as well as the world outside the text. Because of its tendency to accommodate and appropriate antithetical genres and discourses, it seems to me that fictocriticism offers a useful alternative to the aporia of 'post-theory' critical discourses. Moreover, since fictocriticism also 'relies on a sentimental imagination that aims to enhance our capacity to be affected by the 
effects of history', it is hardly surprising that many practitioners of this genre, or mode, are increasingly using the premises of autobiography and poetic discourse to expand-rather than reject-the possibilities of subjective and internal modes of expression. ${ }^{38}$

Dominique Hecq is an honorary research fellow in the School of Creative Arts at the University of Melbourne, where she teaches creative writing and psychoanalysis. Her latest book of fiction is Noisy Blood, Papyrus, 2004.

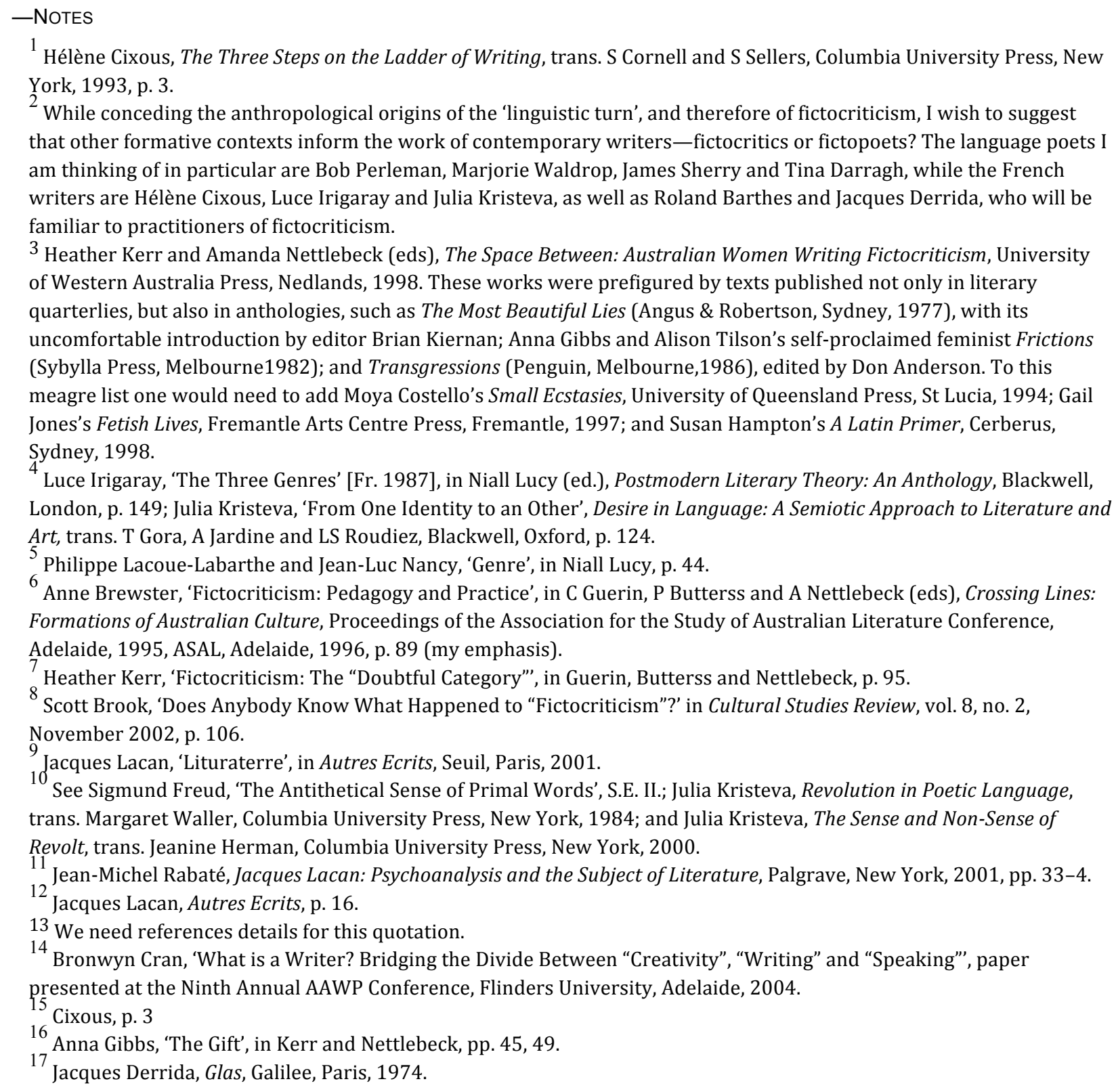


19

${ }^{19}$ Heather Kerr, 'Fictocritical Empathy and the Work of Mourning', Cultural Studies Review, vol. 9, no. 1, May 2003, pp. 187-8.

20 Bob Perelman, The Marginalization of Poetry: Language Writing and Literary History, Princeton University Press, Princeton, 1996, p. 8.

21 Though this partly explains why my own parameters are not strictly around the institutional relations of feminism and poststructuralism, this does suggest questions that are beyond the scope of this paper.

${ }_{23}^{2}$ Dean Kiley, 'Alone, Again: Naturally (and Queerly)', Southerly, vol. 58, no. 3, pp. 125-39.

23 See Beverley Farmer, Alone, Penguin, Ringwood, 1980.

24 See Jeanette Winterson, 'Art and Lies', in Art Objects, Jonathan Cape, London, 2005.

25 p. 16.

26 Gail Jones, Sixty Lights, Harvill, London, 2004.

27 Gail Jones, 'Without Stars (A Small Essay on Grief)', in Heat, vol. 7, 1998, p. 149.

28 Jones, 'Without Stars', p. 143.

29 Alain Badiou, Infinite Thought: Truth and the Return of Philosophy, trans. Justin Clemens and Oliver Feltham, Continuum, New York, 2004, p. 103.

30 AR Chisholm and JJ Quinn (eds), The Prose of Christopher Brennan, Sydney, Angus \& Robertson, 1962 , p. 39.

31 Steven Maras, 'Notes on a Genre to Come: Screenwriting and the "Thesis-Film”', Cultural Studies Review, vol. 10. no. 2, September 2004, pp. 85-99.

32 See Cultural Studies Review, vol. 8, no. 2, November 2002, for Tara Lee, 'Learning to Read Another Body: The Skin as a Map of Personal Memory', pp. 119-38; 'Michael Farrell, 'Language and Learism', 'The Men Who Read Working Hot', 'The Sound of Reading', pp. 138-42; and 'Stephanie Bishop, 'In the New Hours', pp. 150-7.

33 Jacques Derrida, Acts of Literature, Derek Attridge (ed.), Routledge, New York, 1992, p. 234; John Yau, Edificio Sayonara, Black Sparrow Press, Santa Rosa, 1992, p. 127; Badiou, p. 102.

${ }^{34}$ C Bernstein, 'The Klupsky Girl', Content's Dream: Essays, 1975-1984, Sun \& Moon Press, Los Angeles, 1986, p. 3.

35 Jacques Lacan, Le Séminaire, Livre XX, Encore (1972-73), Seuil, Paris, 1975, p. 120.

${ }^{36}$ Kerr and Nettlebeck, pp. 5, 12.

${ }_{38}^{37}$ Farrell, 'Language and Learism', p. 139.

38 Kerr, 'Fictocritical Empathy', p. 188. 